\title{
Philosophical Meaning in the Syaer's Oral Tradition of Lampung Pepadun
}

\author{
Roveneldo Roveneldo ${ }^{1, *}$, Mukhammad Isnaeni ${ }^{1}$ \\ ${ }^{1}$ National Research and Innovation Agency, Indonesia \\ *Corresponding author.Email: roveneldo2011@gmail.com
}

\begin{abstract}
This study describes the vitality of the oral tradition of Syaer Lampung, which grows and develops in the community of Lampung Pepadun. This effort was made to provide a complete understanding and description of words and sentences in the Syaer's oral literature. The researchers use a qualitative approach in four sets to achieve this goal, namely data collection, data verification, data presentation analysis, and conclusions. Researchers found the philosophical meaning contained in Syaer's oral literature as an advice from ancestors for future generations. The advice inserted in every stanza of Syaer's oral literature is to have a noble character, be responsible, be kind, staying away from detrimental actions to oneself and others. Another philosophical meaning in Syaer's stanza is the command to obey Allah and stay away from His prohibitions. Researchers also found indications of the vitality of Syaer's oral literature, which began to fade among its users. It was found that there was a substantial change in the use of language in Syaer's stanza from Lampung to Indonesian. Based on these findings, the researchers suggested that the conservation for Syaer was necessary.
\end{abstract}

Keywords: oral tradition, syaer, Lampung language, Pepadun, vitality

\section{INTRODUCTION}

The oral tradition, which is called the equation of oral literature in Indonesian society, has the characteristics of a literary work in poetry, prose, singing, and verbal drama. However, some say the same for ordinary humans to signify the difference between oral tradition and oral literature. Not a few also stated differently. In connection with this, Endraswara [1] argues that oral literature is the result of work. Oral tradition is a strategy or a process. Therefore, the oral process that produces literature is called oral literature.

Sibarani [2] states that the word tradition comes from the Latin traderere or tradere meaning 'to transmit, to hand over, and to give for safekeeping.' As a noun category, tradition means a habit passed down from one generation to another for a long time to become part of people's social life. Tradition contains three meanings: 1) knowledge and processes correlate with a sense of continuity and with shared material, customs, and verbal expressions practiced by a group of people; 2) creation and confirmation of identity which relevant to selection; and 3) identification of traditions for those who are still looking for their identity.
On the other hand, from creating or establishing identity through meaningful participation, identification requires people to make efforts. The need for courage and enthusiasm for expressing culture to the community has been inherited from their ancestors. So far, there is evidence that has discussed the oral tradition carried out by Turaeni [3], which describes the function and meaning of the cecangkriman oral tradition for the Balinese people. The findings of the cecangkriman include as a medium for sharpening one's intelligence or reasoning power, as a joke, as a sense of social solidarity, and also as a meaning that can be used as an educational tool in introducing the values of local wisdom, to children, especially oral tradition culture.

There is also a discussion of oral literature expressed by Labbiri [4] regarding the function of kelong oral literature in the people of the Makassar area. Kelong oral literature has a role as a medium of education, entertainment, motivation, and fighting spirit, as a medium of communication, and as a product of cultural preservation.

Badara \& Dinar [5] study oral literature as a 'treasure' of the Tolaki people, who live in Kendari City and Kolaka Regency, Southeast Sulawesi Province. The types of Tolaki oral literature are mosehe, moanggo, kinoho, and folk songs. Folk 
songs (folk songs) are passed down from generation to generation. Folk songs are often not known when it was created and who created them. In general, the people who own it (folk songs) know of their existence through the writings of their predecessors.

However, in general, the meaning contained in folk songs is to express everything related to human life, such as expressions of sadness, sincerity, loyalty, love, and change. The noble values in the folk song's lyrics include being good at understanding the secrets of life, understanding life wisely, and improving character [6].

A visual study of how the oral tradition of gulung was revealed by Mursalin. Through video documentation that can be accessed on YouTube, Mursalin teaches how to preserve the culture left by his ancestors. This art from Ketapang Regency is still maintained, sustainable, and developing even though it is no longer popular. Occasionally this oral tradition is still held at weddings, official government events, circumcisions, and thanksgiving events. The content in gulung is usually about an ongoing event or the stories behind it.

Oral literature has a close relationship with local customs and culture. Oral literature of a community may have diversity. This diversity is a characteristic of certain areas [7]. For example, the Lampung Province area has culture, language, and customs. The Lampung community is one of the people in Indonesia who has two regional languages: dialect $\mathrm{O}$ and dialect $\mathrm{A}$, as well as cultural customs, namely Pepadun and Saibatin, by having each oral tradition that is rich in meaning [8]

Lampung oral tradition plays a role in civilization, outlook on life, association, and others. Lampung oral tradition consists of hahiwang, wawancan or pepaccur, bebandung, talibun, sasikun, saganing or teteduhan, syaer or bubiti, Lampung classic songs, mantra, warahan (folklore), and others. There is also a discussion and study of Lampung literature, expressed by Ariyani \& Liana [9]. They confirmed that Lampung literature has meaning and benefits in human life because Lampung literary works can grow and provide readers with an awareness of the truth of life, even in fiction.

Lampung is very rich in various cultures and traditions. However, Lampung oral literature tends to be less popular since the people, particularly younger generation does not give much appreciation. In addition, the development of science and technology also influenced the development of Lampung oral literature. However, we also need to realize that language and culture are dynamic. Many factors underlie the decrease of oral tradition practices in the province of Lampung. For example, Begawi tradition is only carried out in a wedding ceremony, so it is rarely practiced other than in the marriage events [10].

The word pepadun has the same meaning as the chair of punyimbang, a place on which a person sits in a traditional kingdom and takes the counterweight title from generation to generation. The function of pepadun cannot be occupied by another person. Pepadun is the main attribute of punyimbang mergo or clans, punyimbang tiuh, and punyimbang tribes [10].

It is necessary to identify efforts, especially in the oral literature of syaer (poems), that exist in the Pepadun community. The results of the temporary identification of Lampung's oral tradition have shifted to other languages. It is no longer using the original regional language. This problem needs to be formulated as a problem in Lampung's oral literature research; how is the today condition of the oral tradition of the Lampung pepadun traditional poetry.

This study aims to understand the complete picture in terms of meaning, what is contained in the poem. This research is expected to provide benefits for the scientific development of oral literature. This research will also be one part of academic activities, especially in developing research on local wisdom by placing regional oral traditions as the discussion focus. The results of this study are expected to be one of the essential references in understanding oral literature that is developing in the region because previous research has not discussed Lampung poetry, particularly in Pepadun.

\section{THEORETICAL FOUNDATION}

Studying culture and language is impossible without excavating in specific scientific fields (culture and language) to bring up a research result. To get the findings from the research, there must be a perspective, theory, and practice of assessment. For example, how someone understands and knows the traditions that have been rooted in society. Of course, the tool for expressing one of these cultures uses a theory related to the scientific theory of linguistic anthropology. The scientific theory of linguistic Anthropology is a branch of Anthropology that studies the languages used in various cultures [11]. Likewise, according to Foley in Kartubi [12], linguistic Anthropology is a subfield of Linguistics that focuses on the part of the language in a broader social and cultural context. Therefore, linguistic Anthropology seeks to find the "meaning" behind the use of language and culture.

Language is one of the main contents of culture used to express what is learned and thought by verbal humans. Culture is part of the language spirit. There is 
a universal element that cannot be separated language and culture. For anthropological scientist Koentjaraningrat [13] thinking, "culture" is the totality of the ideas system, actions, and human creations in public life that is made into human beings by learning. It means that almost all human actions are "culture" because only a few human activities in public life do not need to be accustomed to learning. This research places culture, oral tradition, and oral literature as three things that cannot be separated. Culture is understood as a collectivity that contains values, practiced and accepted as a building of similarity that runs dynamically in the life of a community. Concretely, culture can refer to customs, forms of oral tradition, works of art, language, interaction patterns, etc.

Thus, culture is an environmental reality, not only having specific characteristics but also having general characteristics. Furthermore, Koentjaraningrat explained that culture has three forms: a complex of ideas, ideals, values, norms, rules, and so on. Second, a complex of patterned activities and actions of humans in society, and third, as objects made by humans [13]

\section{RESEARCH METHOD}

This research reveals the oral tradition, one of the cultures of the indigenous people of Pepadun, through language studies, which refers to the study of descriptive qualitative methods with a linguistic anthropological approach. The scientific approach of linguistic anthropology is prioritizing how to see conditions to capture reality or phenomena before analyzing work is carried out, which is identical to perspectives, conceptual frameworks, frameworks of thought, intellectual strategies, paradigms, and interpretation techniques [14].

There are three essential roles of descriptive methods in a research: 1) to avoid speculative problem-solving and thinking; (2) to avoid the trialerror solving or working methods; and (3) to improve the nature of objectivity in exploring the truth of knowledge. The descriptive method can be interpreted as a problem-solving procedure investigated by describing the state of research subject or object. With the descriptive method, a researcher must reveal observable facts or data by providing a description [14].

In general, the design of oral literature research uses a qualitative research design. Qualitative research intends to understand the phenomena experienced by research subjects, such as behavior, perceptions, motivations, actions and others holistically, and by way of description in the form of words, such as data in documents, actions, words in the form of information from informants and respondents [15]. Likewise, Sibarani asserts that qualitative research is descriptive research, researchers are interested in processes, meanings, and understandings obtained through words or pictures [16].

Qualitative research uses three methods of data collection, namely in-depth and open interviews, direct participatory observation, and written documents. In-depth and open-ended interviews were conducted to obtain data from informants who study the relationship between language and people and their culture. Direct and participatory observations are carried out by observing the use of language in human culture directly. The written document method is specifically used to find data relating to the scope of linguistic anthropology or anthropological linguistics. The analytical method used is an interactive model of qualitative analysis procedures. After collecting data, there are three activities in qualitative analysis, namely data condensation, data presentation, and conclusion drawing/verification [17]

\section{DISCUSSIONS}

The wedding ceremony is a procession for humans to carry out the legitimacy and follow religious and state laws. The series of wedding events must carry out the culture and traditions according to the region of the country and ethnicity that have various kinds of cultures. In Lampung, for example, there is a tradition called syaer (syair). The oral tradition, called poetry, belongs to the Lampung pepadun custom, which is carried out at weddings, whether a traditional event or a national wedding party. In general, the meaning of syaer is an old poetry where each stanza consists of four lines (lines) ending with the same sound [11].

In Lampung tribe poetry, each stanza consists of two, three, four, five, and six lines with the same final vowel-consonant at the end of the letter. Therefore, the sounds are pretty poetic and charming. However, the majority of each Lampung verse consists of four stanzas. The following is only some stanzas of a Lampung poem read in a wedding.

Ikam segajou temegei di depan

Ayen wat sai ngesong agou ku sayan

Balak ateiku mak kebayangan

Appu kuw Rahmad Gustian kak ngemek pasangan

Lamen niat kemaman keminan

Tengguw pai ram dapok lem kemampuan

Opounou ram sekedar merencanakan

Tuhan jua sai menentukan

Para undangan nayah kak bettoh

Sekianlah tegoh jou gawoh 
The English translation is:

I intentionally come forward

It's not ordered but my own will

My happiness is indescribable

My grandson, Rahmad Gustian has found his other half

If uncle and aunt have good intention

Just wait, we will have ability

We can only plan

God the One deciding

All invitees are starving

My poem, it ends here

Some of oral traditions Lampung have, one of which is poetry. It has a deep value and sense in terms of meaning. Likewise, the content of philosophy in the poem, the message in the poem is to give love, care, and learning in life and the hereafter. By understanding the contents, we will treasure the life. It shows examples and experiences of nobility in the past.

Like the example of the poem above, the first stanza is the speaker starts reciting the poem by asking permission. It expresses the gratitude to all guests and family. The second and later parts of poem provide advice and messages. Since it is expressed in a wedding ceremony, the poem consists of messages for family and the in-law family. It also contains prays for the married couple and family. In the final stanzas, the reciter does not forget to close the poem by apologizing and bidding farewell.

The use of language in this poem is to use a parable language style that focuses on de-personification style. There are sentences using presuppositions explicitly in the words kalau, jika jikalau, bila(mana), sekiranya, misalkan, umpama, andai(kata) seandainya andaikan [18].

Many values can be learned from the poetry. It teaches to live the life, and face the problem. The function of this Lampung verse is, absolutely, to strengthen human identity to lead a new family, to be careful and patient in going through the life, and not to decide everything in a hurry. The essence of human life is to stay away from all prohibitions regulated by religion and state. Hopefully, this oral tradition can be maintained because it is an intangible asset owned by the community that is full of good values.

The researchers present another example of Lampung pepadun poem (only some of 16 parts are written here). However, the poem below shows that there is a change in the writing because it is not purely in Lampung language. Indonesian language is used before the reciter shifts it to the local language.
Takbir Allah azan wajalla

Nakanda Hendra dengan SP betuah nasibnya

Mempersunting seorang wanita pilihannya

Nakanda Ulfa Nadia, S.Pd itulah namanya

Wanita intelek cerdas masa kininya

Mendapatkan jodoh memang tanda tangannya

Sama-sama keturunan bangsa ternama

Putri ke-8 dari Bapak Iszuar dan ibu Naimah yang jelita

Hari ini hari kewaktunya

Silaturahmi berbaur rasa

Kakak adik lebuw kelamou anak bai menunglung

Dari Pagardewa, Waikanan,

Kotabumi, Menggala, dan yang di Bandar Lampung

Tulus iklas semua mendukung

Gawi terbukti memang termasur

Keluarga besar datuk Raden Syafei keluarga besar

Haji Muhammad Syafei berbudi luhur

Berjiwa besar damai dan akur

Allhamdulilah terima syukur

Ayah Drs Haji Majekker HN

Wak Usup, Zakaria Raup

Beliau berdoa

Ya Allah Dia menghafalkannya

Rukunlah damai kalian bedua

Semoga menjadi keluarga

Yang

Sakinah

Mawadah

Warohmah

Sampai disini syair alkisah

At the beginning of the poem, as usual, the characteristics of Lampung poetry is to greet and ask for permission to deliver poetry in front of the crowd or on stage. Such words usually present in the first and second stanzas. The stanzas after greeting express that the groom has met the woman of his choice, while also stating that they both are from family with very good background.

The words used in this poem are comparative styles that focus on metaphorical language. Tarigan [18] suggested that metaphor is a type of comparative language that is the shortest, densest, and neatly arranged.

In the sixth and later stanzas, there is a codemixing and switch from Indonesian to Lampung regional language, such as the words lebuw, kelamou, anak bai, menulung. The meaning of these words is the groom's greeting to his close relatives. The 
word lebuw is a greeting from the groom to the family of his father. Meanwhile, kelamou means the groom's greeting to his mother's family. The word anak bai refers to the nephew of the groom's father and menulung is a greeting from the groom's father and his sister's family.

The following stanzas express the groom asking the blessing for the event to run smoothly. It contains a pray that the married couple will get bless in the world and hereafter; blessing to build a new family and continuing the family line. It is shown in the use of Arabic terms sakinah mawaddah wa rahmah. There is also stanza containing the strong support of the big family. In the end, the poet said goodbye by quoting the old phrases in Lampung "Jangan dibincang berbadan salah sama-sama mengingat firman Allah wahai kasihmu kita berpisah" which means that all humans make mistake so there is no need to gossip behind one's back.

How memorable the poem is, with many words expressing the happiness and character values. It does not hurt, yet, becomes the exemplary for people since it consists of the ancestors' advice. It teaches us to avoid anything that harms ourselves; to obey God's commands; and to stay away from all His prohibitions.

\section{CONCLUSION}

In the traditional system of Lampung culture, what the ancestors left behind is still considered applicable in today life. It has been proven that Lampung poetry has an excellent mandate to forge the next generation of the family, nation, and religion. It was giving instructions or advice by reminding each other, reflecting on the bad experiences, not letting the generation fall into negative things, and constantly developing positive values.

This oral tradition of poetry puts forward the value of honesty, patience in facing all trials, not easily provoked by irresponsible people, politeness, respecting each other, tolerance, piety to the Almighty. Apart from the excellent meaning and philosophy contained in the poem, some problems are pointed out related to the existence of Lampung Pepadun traditional poetry. The problem is that the majority of oral poetry tradition is already old. Only few love or care about this tradition since young people do not appreciate their own culture. Based on this fact, there is a need for conservation and the propagation of the oral tradition of Lampung Pepadun poetry so that this tradition will not extinct.

\section{ACKNOWLEDGMENTS}

The authors would like to express their gratitude to all informants involved in this study: and say their thankfulness to the anonymous reviewers for their insight and suggestion for the improvement of this paper.

\section{REFERENCES}

[1] S. Endraswara, Antropologi Sastra Lisan (First edition). Pusaka Obor Indonesia, 2008. https://doi.org/1555.36.109.2018

[2] R. Sibarani, The role of local wisdom in developing friendly city, IOP Conference Series: Earth and Environmental Science, 126(1), 2018. https://doi.org/10.1088/1755-1315/126/1/012094

[3] N. N. T. Turaeni, Fungsi Dan Makna Tradisi Lisan Cecangkriman Bagi Masyarakat Bali. Bebasan, 7 No 1, Ed, 15-28, 2020.

[4] Labbiri. Sastra Kelong (Pertama). Cv. Kanaka Media,2018.https://eservice.lipipress.lipi.go.id/pr ess/catalog/view/267/224/599-1

[5] A. Badara, S. S. Dinar, Sastra lisan Mosehe, Moanggo, Kinoho, dan Nyanyian Rakyat 'Harta Karun Orang Tolaki (Marwati (ed.); Pertama). Universitas Halu Oleo Press Kampus Hijau Bumi Tridarma Jalan Eddy A. MokodompitKendari93231, 2020. https://eservice.lipipress.lipi.go.id/press/catalog/view/tol aki/233/615-1

[6] Roveneldo. Gaya Bahasa Repetisi Lagu Klasik Lampung Dialek O Dalam Kajian Linguistik Antropologis. MABASAN, 13(2), 137-150, 2019. https://doi.org/10.26499/mab.v13i2.252

[7] S. Sudrajat, W. P. Mulyani, A. Saikhu, Perubahan Socio-Culture dan Economic Separation Keluarga dan Pengaruhnya terhadap Kehidupan Lansia di Desa Tileng Kecamatan Girisubo. Majalah Geografi Indonesia, 33(1), 68, 2019. https://doi.org/10.22146/mgi.41255

[8] Roveneldo. Tinjauan Etnolingguistik Pada Kosakata Bidang Perikanan Bahasa Lampung Dialek Tulangbawang. Kelkelepot, 14 (Pendataan nama-nama ikan sungai Tulangbawang), 88-98, 2018.

[9] F. Ariyani, R. Liana, Sastra Lampung (First Edition). Graha Ilmu, 2018.

[10] Roveneldo. Prosesi Perkawinan Adat Istiadat Lampung Pepadun: sebagai Bentuk Pelestarian Bahasa Lampung. Ranah: Jurnal Kajian Bahasa, 6(2) 220, 2017. https://doi.org/10.26499/rnh.v6i2.265 
[11] KBBI. In Cetakan Ketiga (Edisi Keli). CV. Adi Perkasa, 2018.

[12] Kartubi, Linguistik Antropologi: Disiplin Ilmu yang Termarjinalisasi pada Program Studi Linguistik, Jurnal Antropologi: Isu-Isu Sosial Budaya 19(1) (2017) 1-10.

[13] Koentjaraningrat. Pengatar Ilmu Antropologi (10th ed.). PT Reneka Cipta, 2015.

[14] Siswatoro. Metode Penelitian Sastra (J. Yuniarto (ed. Empat). Pustaka Pelajar, 2016.

[15] D. Sulistyorini, E. F. Andalas, Sastra Lisan Kajian Teori dan Penerapannya dalam Penelitian (Pertama). Madani Kelompok Intrans Publishing, 2017. www.intranspublishing.com
[16] R. Sibarani, Anthropolinguistics as Interdiciplinary Approach. Journal of Anthropolinguistics, 1(1), 1-8, 2020

[17] M. B. Miles, et al. Analisis Data Kualitatif. In Nursing standard (Royal College of Nursing (Great Britain) : 1987) (3rd ed., Vol. 30, Issue 25). Los Angeles: Sage, 2016. $\underline{\text { https://doi.org/10.7748/ns.30.25.33.s40 }}$

[18] H. G. Tarigan, Pengajaran Gaya Bahasa, CV. Angkasa, 2013 